\title{
Quality Characteristics of Imported Specialty Coffee According to Origin
}

\author{
So-Young Lee ${ }^{1}$, Myung-Ryun $\mathrm{Han}^{2}$, Ae-Jung Kim ${ }^{3 *}$ \\ ${ }^{1}$ Department of Alternative Medicine, Kyonggi University, Seoul, Korea \\ ${ }^{2}$ Department of Baking Science \& Technology, Hyejeon University, Hongseong-gun, Chungcheongnam-do, Korea \\ ${ }^{3}$ Department of Nutrition Therapy, The Graduate School of Alternative Medicine, Kyonggi University, Seoul, Korea
}

\author{
*Corresponding author: Ae-Jung Kim, \\ Department of Nutrition Therapy, The \\ Graduate School of Alternative Medicine, \\ Kyonggi University, 63, Kyonggidae-ro-9 gil, \\ Seodaemun-gu, Seoul 03752 Korea \\ Tel.: +82 22905044 \\ Fax: +8223905078 \\ Email: aj5249@naver.com
}

Received November 5, 2019

Revised December 12, 2019

Accepted December 13, 2019

Published December 30, 2019

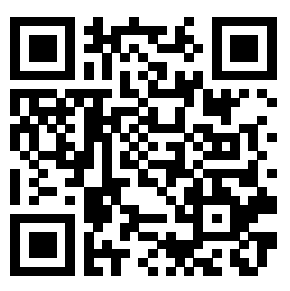

\begin{abstract}
Purpose: This study was performed to determine the best-blended specialty coffee for customers upon sampling and evaluating the quality characteristics of five kinds of coffee, Colombia Supremo (CS), Costa-rica Tarrazu (CT), Colombia Supremo Decaffeine (CSD), Indonesia Mandelling (IM), and India Robusta (IR). Methods: Five kinds of specialty coffee green beans were extracted after roasting, and we measured the $\mathrm{pH}$, brix, solid contents, caffeine, theobromine, trigonelline, and chlorogenic acid contents, and 1,1-diphenyl-2-picryl-hydrazyl (DPPH) radical scavenging activities. Results: The $\mathrm{pH}$ of IR was the highest at $5.71 \pm 0.01$, the ${ }^{\circ}$ brix and solid contents were the highest in CS at $1.20 \pm 0.10^{\circ} \mathrm{Brix}$ and $0.83 \pm 0.05^{\circ} \mathrm{Brix}$, respectively. Total branched chain amino acids $(63.58 \pm 0.12 \mathrm{mg} / \mathrm{g})$ and the sum of taste-related amino acids, such as serine, alanine, glutamic acid $(67.84 \pm 0.10$ $\mathrm{mg} / \mathrm{g}$ ), were the highest in CS. In IR, caffeine content was the highest as well as theobromine $(29.32 \pm 0.07 \mathrm{mg} / \mathrm{g}$ and $0.74 \pm 0.01 \mathrm{mg} / \mathrm{g}$, respectively). Meanwhile, CSD showed the highest contents of trigonelline and chlorogenic acid $(0.97 \pm 0.02$ $\mathrm{mg} / \mathrm{g}$ and $0.94 \pm 0.01 \mathrm{mg} / \mathrm{g}$, respectively). The DPPH radical scavenging activity of CS was at $90.54 \pm 0.18 \%$, which was the highest among the tested coffees. Conclusion: Among the five kinds of specialty coffees, CS had the high solid contents and superior DPPH radical scavenging activities, and CSD has high levels of trigonelline and chlorogenic acid, but low levels of caffeine. If they were blended, this new specialty coffee would have high levels of anti-oxidative activities with a good taste and a low amount of caffeine.
\end{abstract}

Keywords: Specialty coffee, Caffeine, Theobromine, Trigonelline, Chlorogenic acid

\section{Introduction}

최근 우리나라는 외식산업의 성장과 더불어 음료시장이 다양해 지면서 소비자들의 선택의 폭이 넓어지고 있다. 특히, 경기불황 에도 불구하고 커피시장의 규모는 2008년부터 현재까지 지속적 으로 꾸준히 증가하고 있는 실정이다(Kim \& Lee, 2015). 국민건 강영양조사(2012년-2015년) 보고서에 따르면 19-64세 성인의 경우 주 11 회 이상 커피를 마시는 것으로 나타났다(Yeon \& Bae, 2019). 이는 커피가 우리나라 사람들에게 생활 밀착형 음료로 자 리 잡았기 때문으로 분석된다(Lee \& Yi, 2016).

커피의 어원은 'caffa'라는 아랍어에서 유래되었으며, 에티오
피아는 아라비카 커피의 원산지로 커피의 고향으로 알려져 있다 (Kim \& Lee, 2015). 약 1,000여 년 전 의학자 라세르(Laceur) 가 커피즙이 위장에 좋은 약재임을 강조하였고, 1 세기쯤 후에는 철학자인 이븐시나(Avicenna)가 커피를 기호음료라고 최초로 언 급하였다(Kim, 2016). 커피는 처음 발견된 당시부터 독특한 맛 과 향으로 많은 사람들을 매료시켰으며 지금은 전 세계 각국 사람 들이 가장 즐겨 마시는 기호음료로 자리매김하고 있다(ColonnaDashwood, 2017).

커피는 생두의 품종, 토양, 취급방법에 따라 영양성분의 함량이 다르나, 일반적으로 건조된 생두에는 10-13\%의 수분, 37-60\% 의 탄수화물, $9-18 \%$ 의 지질, $11-13 \%$ 의 단백질, $3.0-4.5 \%$ 의 
무기질, $5.5-10 \%$ 의 클로로겐산(chlorogenic acid)과 $0.9-2.4 \%$ 의 카페인(caffeine)이 함유되어 있다(Kim \& Han, 2009). 또한 커피에는 다양한 향기성분이 함유되어 있어 커피 생두를 로스팅 하여 추출 공정을 거칠 때 커피의 맛과 품질에 영향을 주게 된다 (Seo et al., 2006). 커피에 포함되어있는 주된 항산화물질은 클 로로겐산(chlorogenic acid)과 폴리페놀(polyphenol) 물질로 하루 에 2 잔 이상의 커피를 섭취하면, 1 일 섭취하는 항산화물질의 많은 부분이 커피에서 충당될 수 있다는 보고(Yeon \& Bae, 2019)가 있 다. 또한 커피 로스팅 시 생성되는 멜라노이딘(melanoidin)도 항 산화 효능이 있다고 알려져 있다(Sacchetti et al., 2009).

커피에 함유된 caffeine은 1820년 스위스의 생리학자 룬게 (Runge)에 의해 커피콩에서 처음 발견된 물질(Jeong \& Lee, 2013)로, 중추신경계를 자극하여 정신을 맑게 하고, 소화기능을 원활하게 하고, 심장 기능을 촉진하는 등의 긍정적인 기능을 한다 는 보고가 있다(Choi \& Lee, 2008). 반면, 임산부가 커피를 다량 소비하면 뇌혈관 장벽이나 태반 장벽을 자유로이 통과하여 태아 에게 부정적인 영향을 주었다는 보고(Mongraw-Chaffin et al., 2009)와 갱년기 여성이 하루에 $300 \mathrm{mg}$ 이상의 카페인을 섭취하 는 경우 골반의 골 소실이 증가하였다는 보고(Park et al., 2014) 가 있다. 그리고 카페인이 함유된 음료 섭취 시 철분 흡수를 방해 했다는 연구(Lim, 2017)와 커피 섭취 시 카페인이 소화불량, 수 면장애, 불안증 등을 유발했다는 보고(Kim \& Chung, 2017) 등 커피의 카페인이 인체에 유해성이 있다는 부정적인 보고들도 있 다.

이러한 카페인의 단점에 대한 연구 보고에도 불구하고 우리나 라 생두 수입량은 2008년 이후 2017년까지 평균 $16 \%$ 의 성장률을 보였고, 각 산지별로 $50 \%$ 이상의 높은 성장률을 나타내 매년 양 적으로 상승세를 보였다(Ji \& Lee, 2019). 또한 커피소비 성향이 고급화됨에 따라 고품질의 스페셜티 커피의 수입량 또한 증가하고 있고(Ji \& Lee, 2019; Ko et al., 2017), 프랜차이즈 업체에서는 소비자들의 고급화 니즈에 맞춰 스페셜티 커피를 판매하기 시작했 다(Kim \& Lee, 2015).

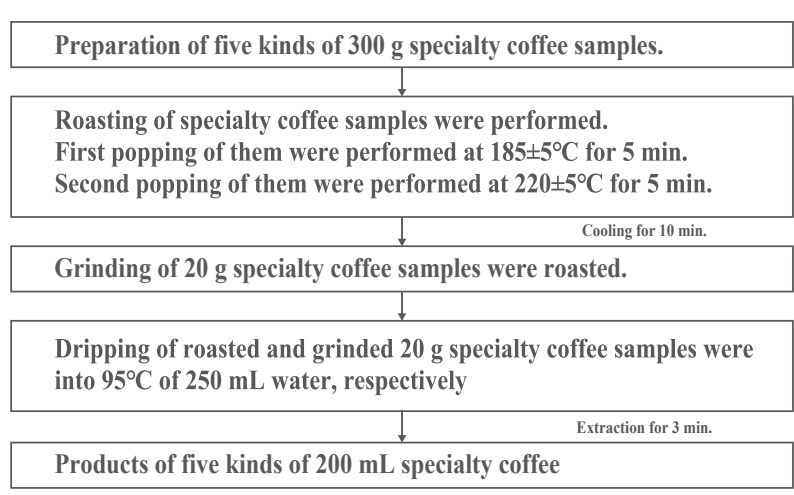

Figure 1. Procedure of roasting and drip of specialty coffee samples.

SCAA(Specialty Coffee Association of America)에서 정의한 스페셜티 커피(specialty coffee)의 조건은 다음과 같다. 첫째, 생 산이력(Traceability)이 명확하여 어느 나라 어느 지역의 어느 농 장에서 재배했는지에 대한 이력을 추적할 수 있어야 한다. 둘째, 재배지역의 고도, 기후, 토질에서 재배된 생두여야 한다. 셋째, 높 은 고도에서 재배된 커피일수록 등급이 높다. 넷째, 향미 평가를 실시하는데 큐그래이더(Q-grader)의 컵핑(cupping)의 관능평가 를 통해 90점 이상을 스페셜티 커피 레어, 85-90점 이하를 스페 셜티 커피 오리진, 80-85점 이하를 스페셜티 커피라고 정의한다. 다섯째, 생두를 신선하게 관리·보관하고 로스팅을 통해 고유의 향 미가 최대한 발현되어야 한다. 여섯째, 숙련된 바리스타가 적절한 기구를 사용하여 추출하여야 한다. 일곱째, 항상 균일한 맛과 향 을 유지할 수 있어야 한다(Kim, 2016).

우리나라의 커피산업은 세계의 커피산업 동향에 편승하여 고품 질의 스페셜티 커피의 수입량이 지속적으로 증가하고 있는 실정이 다(Ji \& Lee, 2019). 그러나 이러한 고품질 스페셜티 커피의 수요 증가에도 불구하고 스페셜티 커피에 대한 생리활성을 포함한 품질 평가 연구는 매우 드문 실정이다.

따라서 본 연구에서는 Ji \& Lee (2019)의 연구에서 보고

Table 1. HPLC conditions for free amino acids analysis of specialty coffee samples

\begin{tabular}{ll}
\hline Items & HITACHI model (L-8800), Hitachi, Ltd. Japan \\
HPLC & Lithum form, Cation exchange resin \\
Mobile phase & Pump 1: buffer solution (lithium citrate) \\
Oven temperature & Pump 2: Ninhydrin reagents \\
& $135^{\circ} \mathrm{C}$ \\
Flow rate & Pump 1: $0.35 \mathrm{~mL} / \mathrm{min}$ \\
& Pump 2: $0.3 \mathrm{~mL} / \mathrm{min}$ \\
UV detector & Channel 1: $570 \mathrm{~nm}$ \\
& Channel 2: $440 \mathrm{~nm}$ \\
\hline
\end{tabular}


한 수·출입 통계 자료를 근거하여 국내의 수입 중량이 지속적으

로 증가한 콜롬비아(colombia supremo, colombia supremo decaffeine), 코스타리카(costa-rica tarrazu), 인도네시아 (indonesia mandelling), 인도(india robusta)에서 수입한 5종류 의 스페셜티 커피의 생리활성 평가를 통해 우수한 품종 2 종을 선 정하여 블렌딩 한 새로운 스페셜티 커피를 소비자에게 제공하고자 하였다.

\section{Methods}

\section{1. 실험재료}

본 연구의 실험재료로 사용한 스페셜티 커피시료인 Colombia Supremo(CS), Costa-rica Tarrazu (CT), Colombia Supremo Decaffeine (CSD), Indonesia Mandelling (IM), India Robusta (IR)는 GSC International (Seoul, Korea)과 (주)구띠에 (Kyeonggido, Korea)를 통하여 일괄 구매하였다.

\section{2. 로스팅 및 추출}

5 종류의 스페셜티 커피 생두 $300 \mathrm{~g}$ 씩을 각각 커피 로스터기 (Proaster THCR-005; Taehwan, Korea)를 사용하여 로스팅 하였다. 로스팅 조건은 1 차 펍핑(popping)을 $185 \pm 5^{\circ} \mathrm{C}$ 로 유지 하고, 2차 펍핑(popping) 및 로스팅(roasting) 완료 구간을 220 $\pm 5^{\circ} \mathrm{C}$ 까지 $5 \mathrm{~min}$ 로스팅한 다음 $10 \mathrm{~min}$ 냉각하였다. 냉각한 원 두는 $20 \mathrm{~g}$ 으로 정량하여 분쇄한 후 칼리타 도자기 드립퍼 세트
(Kalita 102LD; Kalita, Japan)를 사용하여 $95^{\circ} \mathrm{C}$ 의 물 $250 \mathrm{~mL}$ 로 $3 \mathrm{~min}$ 추출하였으며, 그 과정은 Figure 1에 제시된 바와 같다.

\section{3. 실험 내용}

1) 색도 측정

5종류의 스페셜티 커피 추출액의 색도 변화는 색도계(Chroma Meter Cr-300; Minolta, Japan)를 이용하여 3회 반복 측정하여 L값(lightness), a값(redness), b값(yellowness)을 산출하였다.

\section{2) $\mathrm{pH}$ 및 당도 측정}

5 종류의 스페셜티 커피 추출액의 $\mathrm{pH}$ 는 $\mathrm{pH}$ meter (MP225; Mettler toledo, Swiss)로 3회 반복 측정하였으며, 당도는 당도

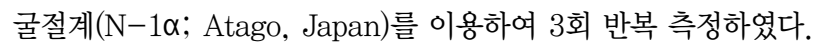
$\mathrm{pH}$ 및 당도의 측정 시 시료의 온도는 $25 \pm 2{ }^{\circ} \mathrm{C}$ 로 하였다.

\section{3) 고형분 함량 측정}

5 종류의 스페셜티 커피의 고형분 함량 $(\mathrm{w} / \mathrm{v} \%)$ 은 상압가열 건조 법을 이용하여 측정하였다.

\section{4) 아미노산 함량 측정}

5 종류의 스페셜티 커피 추출시료의 유리 아미노산 함량은 1 $\mathrm{mL}$ 를 정량하여 $4 \mathrm{~mL}$ URIPREP 용액에 현탁하고, 이를 상온 에서 $5 \mathrm{~min}$ 방치 후 $13,000 \mathrm{rpm}$ 으로 $10 \mathrm{~min}$ 원심분리한 다음 $0.45 \mu \mathrm{m}$ membrane filter (PVDF-2545; Chemco Scientific, Japan)로 여과한 액을 high pressure liquid chromatography

Table 2. HPLC conditions for caffeine, theobromine, trigonelline, chlorogenic acid of specialty coffee samples

\begin{tabular}{ll}
\hline Items & \\
HPLC & HITACHI model $(655 \mathrm{~A}-11)$, Hitachi, Ltd. Japan \\
Column & Inertsil ODS-3 $(5 \mu \mathrm{m}, 5.0 \times 250 \mathrm{~mm})$ \\
Mobile phase & Acetonitrile $(10 \mathrm{mM}): \mathrm{KH} 2 \mathrm{PO} 4(10 / 90, \mathrm{v} / \mathrm{v})$ \\
Column temperature & $30^{\circ} \mathrm{C}$ \\
Flow rate & $0.9 \mathrm{~mL} / \mathrm{min}$ \\
UV detector & $280 \mathrm{~nm}($ Shimadzu SPD-10 A VP) \\
\hline
\end{tabular}

Table 3. Color values of specialty coffee samples

\begin{tabular}{lccc}
\hline Samples & $\mathrm{L}^{*}$ & $\mathrm{a}^{*}$ & $\mathrm{~b}^{*}$ \\
CS & $36.06 \pm 0.51^{1 / \mathrm{a} 2)}$ & $7.50 \pm 0.10^{\mathrm{b}}$ & $15.60 \pm 0.36^{\mathrm{b}}$ \\
CT & $32.83 \pm 1.88^{\mathrm{c}}$ & $12.10 \pm 4.03^{\mathrm{a}}$ & $15.09 \pm 1.47^{\mathrm{bc}}$ \\
CSD & $38.27 \pm 0.50^{\mathrm{a}}$ & $6.75 \pm 0.14^{\mathrm{b}}$ & $17.49 \pm 0.30^{\mathrm{a}}$ \\
IM & $39.06 \pm 1.64^{\mathrm{a}}$ & $6.84 \pm 0.53^{\mathrm{b}}$ & $18.58 \pm 1.00^{\mathrm{a}}$ \\
IR & $36.06 \pm 0.51^{\mathrm{b}}$ & $7.50 \pm 0.10^{\mathrm{b}}$ & $15.60 \pm 0.36^{\mathrm{b}}$ \\
\hline
\end{tabular}

CS, Colombia Supremo; CT, Costa-rica Tarrazu; CSD, Colombia Supremo Decaffeine, IM, Indonesia Mandelling; IR, India Robusta; L*, lightness; a*, redness; b*, yellowness.

${ }^{1)}$ Mean \pm standard deviation.

${ }^{2)}$ Different superscripts within a column (a-c) indicate significant differences $(p<0.05)$. 
(HPLC)로 분석하였다. 유리 아미노산의 분석조건은 Table 1과 같 다.

5) Caffeine, theobromine, trigonelline 및 chlorogenic acid 함량 분석

5 종류의 스페셜티 커피 추출액의 카페인(caffeine), 테오브 로민(theobromine), 트리고넬린(trigonelline), 클로로겐산 (chlorogenic acid)의 함량은 스페셜티 커피 추출액을 각각 10 $\mathrm{mL}$ 를 취하여 비커에 넣고 증류수를 $100 \mathrm{~mL}$ 씩 첨가하였다. 이 를 각각 $20 \mathrm{~mL}$ 씩 취하여 $50 \mathrm{~mL}$ 의 메스플라스크에 넣고, $1 \mathrm{~mL}$ 의 lead acetate를 첨가하여 10 분간 방치한 다음, $10 \%(\mathrm{w} / \mathrm{v})$ $\mathrm{Na}_{2} \mathrm{CO}_{3} 1 \mathrm{~mL}$ 를 첨가하여 잘 혼합하였다. 그 후, 시료를 $1 \mathrm{~mL}$ 씩 취하여 $0.45 \mu \mathrm{m}$ membrane filter로 여과하여 HPLC로 분석하였 으며, 이때의 분석조건은 Table 2 와 같다.

\section{6) DPPH radical 소거능 측정}

항산화 활성은 1,1-diphenyl-2-picryl-hydrazyl(DPPH; Sigma-Aldrich, USA) 라디칼에 대한 전자공여능(electron donating ability)으로 5 종류의 스페셜티 커피 추출액에 대한 환 원력을 측정하였다(Blois, 1958). 여과한 스페셜티 커피 용액 0.1 $\mathrm{mL}$ 에 $1.5 \times 10^{-4} \mathrm{M} \mathrm{DPPH}$ 를 첨가하여 상온의 암실에서 $30 \mathrm{~min}$ 방치한 후, 분광광도계(Model DU 530; Beckman, USA)를 이용 하여 $517 \mathrm{~nm}$ 에서 흡광도를 측정 대조군 대비 소거능을 산출하였 다.

\section{4. 통계 처리}

본 실험결과는 Statistical Package for Sciences (SPSS ver.
24.0 program; SPSS Inc, USA) 프로그램으로 통계분석을 실 시하였고 3 회 반복 측정한 결과 값을 이용하여 Mean $\pm \mathrm{SD}$ 를 구 하였다. 시료 간의 유의성을 알아보기 위한 분산분석(one-way ANOVA)을 실시하였으며, Duncan's multiple range test를 이용 하여 $p<0.05$ 수준에서 사후검정을 실시하였다.

\section{Results and Discussion}

\section{1. 색도}

5종의 스페셜티 커피 추출물 시료의 색도를 측정한 결과는 Table 3 에 제시된 바와 같다.

$\mathrm{L}^{*}$ 값은 39.06-32.83의 범위를 나타내었으며, 각 시료들 중 $\mathrm{IM}$ 의 L 값이 $39.06 \pm 1.64$ 로 가장 높았고, CT가 $32.83 \pm 1.88$ 으 로 가장 낮았다. $\mathrm{a}^{*}$ 값은 12.10-6.75의 범위로 나타났고, CT가 $12.10 \pm 4.03$ 으로 가장 높았으며, CSD가 6.75 0.14 으로 가장 낮게 나타났다. $b^{*}$ 값은 18.58-15.09의 범위로 나타났고, IM이 $18.58 \pm 1.00$ 으로 가장 높았으며, CT가 $15.09 \pm 1.47$ 으로 가장 낮았다. Seo et al. (2003)의 레귤러 커피의 색도 측정결과를 보 면 L*값은 42.08-53.92, a 값은 20.77-26.45, b 값은 26.5631.23 의 범위로 나타나 본 시료인 스페셜티 커피는 레귤러 커피 에 비해 명도, 적색도, 황색도 모두 낮게 나타났는데, 이는 로스팅 조건 차이에 의한 영향으로 보여진다.

\section{2. $\mathrm{pH}$ 와 당도}

5 종의 스페셜티 커피의 추출물 시료의 $\mathrm{pH}$ 와 당도를 측정한 결 과는 Table 4 에 제시된 바와 같다. $\mathrm{pH}$ 값은 5.71-5.20의 범위

Table 4. $\mathrm{pH},{ }^{\circ}$ brix(\%) of specialty coffee samples

\begin{tabular}{lcr}
\hline Samples & $\mathrm{pH}$ & ${ }^{\circ} \mathrm{Brix}(\%)$ \\
CS & $5.22 \pm 0.02^{1) \mathrm{a} 2)}$ & $1.20 \pm 0.10^{\mathrm{a}}$ \\
CT & $5.30 \pm 0.01^{\mathrm{b}}$ & $0.96 \pm 0.21^{\mathrm{b}}$ \\
CSD & $5.20 \pm 0.01^{\mathrm{c}}$ & $0.26 \pm 0.06^{\mathrm{e}}$ \\
IM & $5.26 \pm 0.01^{\mathrm{c}}$ & $0.34 \pm 0.06^{\mathrm{d}}$ \\
IR & $5.71 \pm 0.01^{\mathrm{a}}$ & $0.46 \pm 0.12^{\mathrm{c}}$ \\
\hline
\end{tabular}

CS, Colombia Supremo; CT, Costa-rica Tarrazu; CSD, Colombia Supremo Decaffeine, IM, Indonesia Mandelling; IR, India Robusta. ${ }^{1)}$ Mean \pm standard deviation.

${ }^{2}$ Different superscripts within a column (a-e) indicate significant differences $(p<0.05)$.

Table 5. Soluble solid contents of specialty coffee samples

\begin{tabular}{lccccc}
\hline Samples & CS & CT & CSD & IM \\
Soluble solid (\%) & $0.83 \pm 0.05^{1) \mathrm{a} 2)}$ & $0.71 \pm 0.01^{\mathrm{b}}$ & $0.72 \pm 0.01^{\mathrm{b}}$ & $0.71 \pm 0.02^{\mathrm{b}}$ & $0.81 \pm 0.02^{\mathrm{a}}$ \\
\hline
\end{tabular}

CS, Colombia Supremo; CT, Costa-rica Tarrazu; CSD, Colombia Supremo Decaffeine, IM, Indonesia Mandelling; IR, India Robusta.

1) Mean \pm standard deviation.

2) Different superscripts within a row (a-b) indicate significant differences $(p<0.05)$. 


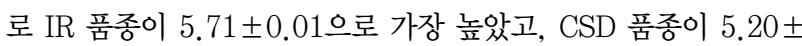
0.01 로 가장 낮았다. 이는 국내에서 시판되고 있는 레귤러 커피의 $\mathrm{pH}$ 가 5.30이라고 보고한 Jang et al. (2017)과 유사한 수준이었 다. Shin et al. (2011)은 커피 품종에 따라 당도의 차이가 나타난 다고 하였는데, 본 연구에서도 시료 간에 당도차이가 나타났으며 그 범위는 $1.20-0.26^{\circ} \mathrm{Brix}$ 이었다. 그 중 $\mathrm{CS}$ 품종이 $1.20 \pm 0.10$ ${ }^{\circ} \mathrm{Brix}$ 로 가장 높았고, $\mathrm{CSD}$ 품종은 $0.26 \pm 0.06{ }^{\circ} \mathrm{Brix}$ 로 가장 낮았 다.

\section{3. 고형분 함량}

커피의 고형분의 함량은 커피의 품종에 따라 그 함량이 다양한 데, 커피의 맛과 색, 향 등에 영향을 주는 중요하게 작용한다(Eun et al., 2014; Kim et al., 2007). 따라서 본 연구에서는 5종의 스 페셜티 커피의 고형분 함량을 비교 측정하여 Table 5 에 제시하였 다.

5종의 스페셜티 커피의 고형분 함량은 $0.83 \pm 0.05-0.71 \pm$ $0.01 \%$ 의 범위였으며, 그 중 $\mathrm{CS}$ 품종이 $0.83 \pm 0.05 \%$ 로 가장 많 았다. 이 함량은 Seo et al. (2003)의 레귤러 커피의 고형분 함량 (0.49-0.64)에 비해 높은 수치였다. 즉, 레귤러 커피에 비해 본 연구 시료인 스페셜티 커피의 고형분 함량이 높아 커피의 맛과
색, 향 등에 긍정적인 영향으로 작용할 것으로 보여 진다.

\section{4. 아미노산 함량}

1) 필수 아미노산

커피에 함유된 아미노산의 경우 로스팅 공정 중 화학적으로 분 해되어 0.2-0.3\% 정도로 함유하고 있으며, 특히 필수아미노산 을 많이 함유하고 있다(Shin et al., 2018). 아미노산 중 체내에서 합성될 수 없는 필수아미노산에는 valine, leucine, isoleucine, methionine, threonine, lysine, phenylalanine, tryptophan, histidine, arginine 등이 있다(Shin et al., 2018). 따라서 본 연 구에서는 5 종의 스페셜티 커피 추출액의 필수아미노산 함량을 측 정하여 Table 6 에 제시하였다.

총 필수아미노산은 $\mathrm{CS}$ 품종 $(142.3 \pm 1.63 \mathrm{mg} / \mathrm{g})$ 에 가장 많이 함유되어 있었다. 근골격근의 성장발달과 근 손실을 보충할 수 있 는 분지사슬 아미노산(valine, leucine, isoleucine)도 CS 품종 $(63.58 \pm 0.12 \mathrm{mg} / \mathrm{g})$ 에 가장 많이 함유되어 있었다. 즉, 5 종의 스 페셜티 커피 시료들 가운데 $\mathrm{CS}$ 품종에 분지사슬아미노산(BCAA) 을 포함한 필수아미노산이 가장 많이 함유되어 있었다.

2) Serine, alanine 및 glutamic acid

Table 6. Essential amino acids of specialty coffee samples

\begin{tabular}{lccccc}
\hline Samples & CS & CT & CSD & IM & IR \\
Threonine & $53.22 \pm 0.06^{1 \mathrm{a} 2)}$ & $55.84 \pm 0.25^{\mathrm{a}}$ & $46.17 \pm 0.05^{\mathrm{b}}$ & $26.42 \pm 0.08^{\mathrm{c}}$ & $18.31 \pm 0.06^{\mathrm{d}}$ \\
Valine & $20.24 \pm 0.04^{\mathrm{a}}$ & $19.42 \pm 0.34^{\mathrm{a}}$ & $17.00 \pm 0.09^{\mathrm{b}}$ & $13.85 \pm 0.03^{\mathrm{c}}$ & $13.48 \pm 0.11^{\mathrm{c}}$ \\
Methionine & $2.31 \pm 0.12^{\mathrm{a}}$ & $0.92 \pm 0.03^{\mathrm{b}}$ & $0.82 \pm 0.02^{\mathrm{b}}$ & $0.43 \pm 0.12^{\mathrm{c}}$ & $0.30 \pm 0.02^{\mathrm{d}}$ \\
Isoleucine & $17.68 \pm 0.05^{\mathrm{a}}$ & $15.66 \pm 0.02^{\mathrm{b}}$ & $8.72 \pm 0.03^{\mathrm{c}}$ & $2.60 \pm 0.36^{\mathrm{d}}$ & $2.08 \pm 0.05^{\mathrm{d}}$ \\
Leucine & $25.66 \pm 0.03^{\mathrm{a}}$ & $25.04 \pm 0.65^{\mathrm{a}}$ & $22.71 \pm 0.10^{\mathrm{b}}$ & $18.76 \pm 0.02^{\mathrm{c}}$ & $17.38 \pm 0.09^{\mathrm{d}}$ \\
Phenylalanine & $16.88 \pm 0.87^{\mathrm{a}}$ & $16.41 \pm 0.24^{\mathrm{a}}$ & $12.99 \pm 0.04^{\mathrm{b}}$ & $4.14 \pm 0.05^{\mathrm{c}}$ & $2.91 \pm 0.06^{\mathrm{d}}$ \\
Histidine & $4.02 \pm 0.26^{\mathrm{a}}$ & $3.15 \pm 0.33^{\mathrm{b}}$ & $1.72 \pm 0.03^{\mathrm{c}}$ & $0.07 \pm 0.01^{\mathrm{e}}$ & $0.53 \pm 0.04^{\mathrm{d}}$ \\
Lysine & $1.06 \pm 0.11^{\mathrm{a}}$ & $1.04 \pm 0.02^{\mathrm{a}}$ & $0.72 \pm 0.03^{\mathrm{b}}$ & $0.28 \pm 0.02^{\mathrm{d}}$ & $0.35 \pm 0.02^{\mathrm{c}}$ \\
Arginine & $1.23 \pm 0.09^{\mathrm{a}}$ & $0.19 \pm 0.01^{\mathrm{d}}$ & $0.83 \pm 0.07^{\mathrm{c}}$ & $0.89 \pm 0.01^{\mathrm{c}}$ & $1.03 \pm 0.03^{\mathrm{b}}$ \\
Total & $142.30 \pm 1.63^{\mathrm{a}}$ & $137.67 \pm 1.89^{\mathrm{b}}$ & $111.68 \pm 0.46^{\mathrm{c}}$ & $67.44 \pm 0.70^{\mathrm{d}}$ & $56.37 \pm 0.48^{\mathrm{e}}$ \\
\hline
\end{tabular}

CS, Colombia Supremo; CT, Costa-rica Tarrazu; CSD, Colombia Supremo Decaffeine, IM, Indonesia Mandelling; IR, India Robusta.

${ }_{1}^{1}$ Mean \pm standard deviation.

2) Different superscripts within a row (a-e) indicate significant differences $(p<0.05)$.

Table 7. Taste enhancing free amino acids of coffee samples

(Unit: $\mathbf{m g} / \mathrm{g}$ )

\begin{tabular}{lccccc}
\hline Samples & CS & CT & CSD & IM & IR \\
Serine & $15.66 \pm 0.06^{1 / \mathrm{a} 2)}$ & $14.96 \pm 0.18^{\mathrm{a}}$ & $5.06 \pm 0.02^{\mathrm{b}}$ & $1.87 \pm 0.05^{\mathrm{c}}$ & $1.35 \pm 0.02^{\mathrm{d}}$ \\
Glutamic & $0.07 \pm 0.02^{\mathrm{b}}$ & $0.09 \pm 0.02^{\mathrm{a}}$ & $0.05 \pm 0.01^{\mathrm{b}}$ & - & - \\
acid & $52.11 \pm 0.03^{\mathrm{a}}$ & $51.35 \pm 0.08^{\mathrm{a}}$ & $44.98 \pm 0.09^{\mathrm{b}}$ & $34.65 \pm 0.08^{\mathrm{c}}$ & $27.55 \pm 0.05^{\mathrm{d}}$ \\
Alanine & $67.84 \pm 0.10^{\mathrm{a}}$ & $66.40 \pm 0.28^{\mathrm{a}}$ & $50.09 \pm 0.12^{\mathrm{b}}$ & $36.52 \pm 0.13^{\mathrm{c}}$ & $28.90 \pm 0.07^{\mathrm{d}}$ \\
\hline Total & &
\end{tabular}

CS, Colombia Supremo; CT, Costa-rica Tarrazu; CSD, Colombia Supremo Decaffeine, IM, Indonesia Mandelling; IR, India Robusta.

${ }^{1)}$ Mean \pm standard deviation.

${ }^{2}$ Different superscripts within a row (a-e) indicate significant differences $(p<0.05)$. 
커피에 함유된 아미노산은 물에 잘 녹고 각각 특유한 맛을 가지 고 있어 커피의 맛과 밀접한 관계가 있다고 하였다(Shin et al., 2018). 그 가운데 serine, alanine 및 glutamic acid과 같은 맛 난 맛 성분의 아미노산은 혀의 수용체와 결합하여 맛을 내는데 함량이 높을수록 관능적 기호성이 높다고 알려져 있다(Park et al., 2014). 특히, serine과 alanine은 커피의 단맛과(Flament, 2002), glutamic acid는 맛난 맛과 관련되어 있다(Ko et al., 2017). 따라서 본 연구에서는 serine, alanine 및 glutamic acid 의 3종의 아미노산 함량을 측정하여 Table 7에 제시하였다.

커피의 단맛을 결정짓는 serine과 alanine의 함량의 경우 CS 품종이 $66.77 \pm 0.09 \mathrm{mg} / \mathrm{g}$ 으로 가장 많았다. 커피의 맛난 맛을 결정짓는 glutamic acid은 CT 품종이 $0.09 \pm 0.02 \mathrm{mg} / \mathrm{g}, \mathrm{CS}$ 품 종이 $0.07 \pm 0.02 \mathrm{mg} / \mathrm{g}$ 으로 많이 함유되어 있었다. 즉, $\mathrm{CS}$ 품종 이 커피의 맛을 결정하는 serine, alanine 및 glutamic acid 함량 이 높았다. Kim \& Kim (2017)의 연구에서는 콜롬비아 품종의 경 우 로스팅 시간이 길수록 단맛이 줄어드는 경향이 있으며, 단시간 (약 10-11 $\mathrm{min}$ )으로 로스팅을 하면 단맛이 증가한다고 보고한 바 있는데 본 연구에서도 $\mathrm{CS}$ 의 serine과 alanine의 함량이 가장 높 게 나타나 이전의 연구 결과와 유사한 양상을 나타내었다.

\section{Caffeine, theobromine, trigonelline 및 chlorogenic acid 함 량}

Caffeine, theobromine, trigonelline, 및 chlorogenic acid 성분들은 커피의 품질을 결정하는데 사용되는 중요한 지표물 질들이다. Caffeine과 theobromine 성분은 부정적인 영향을, trigonelline과 chlorogenic acid 성분은 긍정적인 영향을 주는 물
질로 알려져 있다(Lee et al., 2017). Caffeine과 theobromine 은 흥분제와 각성제로 잘 알려진 알칼로이드 물질(Franca et al., 2007)로 caffeine은 중추신경계를 자극하는 각성효과가 있 다(You \& Lee, 2018). Theobromine은 커피, 발효잎차, 카카오 에 함유되어 있는 부정적인 영향을 미치는 성분이다(Yun et al., 2015). 커피 배전공전 중 trigonelline에서 생성되는 휘발성 물질 은 커피의 맛과 향에 긍정적인 영향을 준다(Kim \& Park, 2006). Chlorogenic acid는 세포의 산화적 손상을 예방하고 간을 보호하 는 생리활성 효과가 있다(Lee et al., 2017). 따라서 본 연구에서 는 caffeine, theobromine, trigonelline 및 chlorogenic acid을 측정하여 Table 8에 제시하였다.

Caffeine의 함량은 IR $(29.32 \pm 0.07 \mathrm{mg} / \mathrm{g})$ 품종에 가장 많 이 함유되어 있었으며, $\mathrm{CSD}(0.65 \pm 0.03 \mathrm{mg} / \mathrm{g})$ 품종에 가장 적 게 함유되어 있었다. Kim \& Park (2006)의 연구에서도 로부스타 품종의 커피에서 카페인 함량이 다른 품종의 커피에 비해 약 2 배 정도 높다고 보고하여 본 연구결과와 일치하였다. Theobromine 는 커피와 발효 잎차, 카카오에 많이 함유되어 있는 성분으로 홍 차와 커피에는 거의 유사한 수준이 함유되어 있다(Yun et al., 2015). 본 연구결과 theobromine 함량은 IR $(0.74 \pm 0.01 \mathrm{mg} /$ g) 품종에서 가장 높았고, IM $(0.12 \pm 0.00 \mathrm{mg} / \mathrm{g})$ 품종에서 가장 낮았다. 이 값은 차류에 포함된 theobromine의 함량분포가 0.9$0.1 \mathrm{mg} / \mathrm{g}$ 이라고 보고한 Choi (2009)의 연구 결과와 유사한 수 준이었다. Trigonelline 함량은 CSD $(0.97 \pm 0.02 \mathrm{mg} / \mathrm{g})$ 품종에 서 가장 높았고, IR $(0.18 \pm 0.00 \mathrm{mg} / \mathrm{g})$ 품종에서 가장 낮았다. Chlorogenic acid 함량은 CSD $(0.94 \pm 0.01 \mathrm{mg} / \mathrm{g})$ 품종에서 가 장 높았고, $\mathrm{CS}(0.12 \pm 0.00 \mathrm{mg} / \mathrm{g})$ 품종에서 가장 적었다. 이 수

Table 8. Caffeine, theobromine, trigonelline, chlorogenic acid of specialty coffee samples

(Unit: mg/g)

\begin{tabular}{lcccc}
\hline Samples & Caffeine & Theobromine & Trigonelline & Chlorogenic acid \\
CS & $18.90 \pm 0.06^{1 / \mathrm{b} 2)}$ & $0.16 \pm 0.00^{\mathrm{c}}$ & $0.18 \pm 0.00^{\mathrm{c}}$ & $0.12 \pm 0.00^{\mathrm{d}}$ \\
CT & $13.83 \pm 0.02^{\mathrm{c}}$ & $0.13 \pm 0.00^{\mathrm{d}}$ & $0.30 \pm 0.01^{\mathrm{b}}$ & $0.16 \pm 0.01^{\mathrm{c}}$ \\
CSD & $0.65 \pm 0.03^{\mathrm{d}}$ & $0.33 \pm 0.01^{\mathrm{b}}$ & $0.97 \pm 0.02^{\mathrm{a}}$ & $0.94 \pm 0.01^{\mathrm{a}}$ \\
IM & $19.95 \pm 0.04^{\mathrm{b}}$ & $0.12 \pm 0.00^{\mathrm{d}}$ & $0.34 \pm 0.02^{\mathrm{b}}$ & $0.16 \pm 0.00^{\mathrm{c}}$ \\
IR & $29.32 \pm 0.07^{\mathrm{a}}$ & $0.74 \pm 0.01^{\mathrm{a}}$ & $0.19 \pm 0.01^{\mathrm{c}}$ & $0.82 \pm 0.02^{\mathrm{b}}$ \\
\hline
\end{tabular}

CS, Colombia Supremo; CT, Costa-rica Tarrazu; CSD, Colombia Supremo Decaffeine, IM, Indonesia Mandelling; IR, India Robusta.

${ }^{1)}$ Mean \pm standard deviation.

${ }^{2}$ Different superscripts within a column (a-e) indicate significant differences $(p<0.05)$.

Table 9. DPPH radical scavenging activities of specialty coffee samples

\begin{tabular}{lccccc}
\hline Samples & CS & CT & CSD & IM IR & IR \\
$\begin{array}{l}\text { DPPH radical } \\
\text { scavenging activity } \\
(\%)\end{array}$ & $90.54 \pm 0.18^{1 / \mathrm{a} 2)}$ & $83.31 \pm 0.80^{\mathrm{d}}$ & $85.63 \pm 0.72^{\mathrm{c}}$ & $89.93 \pm 0.71^{\mathrm{b}}$ & $90.40 \pm 1.33^{\mathrm{a}}$ \\
\hline
\end{tabular}

CS, Colombia Supremo; CT, Costa-rica Tarrazu; CSD, Colombia Supremo Decaffeine, IM, Indonesia Mandelling; IR, India Robusta.

${ }^{2)}$ Different superscripts within a row (a-b) indicate significant differences $(p<0.05)$. 
준은 Jang et al. (2017)가 보고한 레귤러커피의 chlorogenic acid의 함량 $(0.1 \pm 0.05 \mathrm{mg} / \mathrm{g})$, Lee et al. (2017)이 보고한 콜 롬비아 커피의 chlorogenic acid 함량 $(0.27 \pm 0.04 \mathrm{mg})$ 보다 도 높은 수준이었다. 즉, 커피 품질에 긍정적인 영향을 미치는 trigonelline와 chlorogenic acid 성분이 가장 많은 품종은 CSD 품종이었으며, 커피 품질에 부정적인 영향을 미치는 caffeine함량 과 theobromine함량은 CSD 품종에서 가장 낮았다.

\section{DPPH radical 소거능}

식품의 항산화 능력은 그 식품이 함유하고 있는 총 폴리 페놀(phenolic compound)의 함량과 관련되어 있다(Kim \& Han, 2009). 커피에는 700여 가지의 휘발성 물질과 향기성분 및 phenol류, phenolic acid류, phenyl propanoid류, 페놀성 quinone류 등을 함유하고 있어 커피의 맛과 품질에 영향을 줄 뿐만 아니라 체내에서 항산화 작용을 하는 것으로 알려져 있다 (Lee et al., 2013; Seo et al., 2003). Karakaya et al. (2001) 은 레드와인보다 커피의 폴리페놀 함량이 높다고 보고하였으며, Nakanishi et al. (2000)은 커피가 LDL-cholesterol의 산화에 대 한 감수성을 줄여, $\mathrm{LDL}$ cholesterol과 malondialdehyde (MDA) 의 감소효과가 있다고 하였다. 따라서 본 연구에서는 5 종류의 스 페셜티 커피 추출액의 항산화성을 알아보기 위해 DPPH radical 소거능을 측정하여 Table 9 에 제시하였다.

5 종류의 스페셜티 커피 시료들의 DPPH radical 소거능을 분석 한 결과 83.31 $\pm 0.80-90.54 \pm 0.18 \%$ 의 범위로 나타났다. 이는 Kim \& Han (2009)의 88.23-91.73\% 범위와 유사한 수준이었 다. 5 종류의 스페셜티 커피 시료들 중 CS 품종이 $90.54 \pm 0.18 \%$ 로 가장 높았고, $\mathrm{CSD}$ 품종이 $85.63 \pm 0.72 \%$ 으로 가장 낮았다. 즉, 5 종류의 스페셜티 커피 시료들 가운데 폴리페놀에 해당하는 trigonelline와 chlorogenic acid의 함량이 가장 높은 CS 커피의 $\mathrm{DPPH}$ radical 소거능이 가장 높음을 알 수 있었다.

\section{Conclusion}

본 연구의 목적은 최근 수입량이 지속적으로 늘고 있는 $\mathrm{CS}$, $\mathrm{CT}, \mathrm{CSD}, \mathrm{IM}, \mathrm{IR}$ 의 품질특성을 평가하여 소비자에게 가장 우수 한 스페셜티 커피 품종을 제시하고자 함이다. 샘플링 한 5 종의 스 페셜티 커피 생두들의 품질특성을 비교하고자 $\mathrm{pH}$, 당도, 고형분 함량, caffeine, theobromine, trigonelline, chlorogenic acid 함량 및 $\mathrm{DPPH}$ radical 소거능을 측정하였다. $\mathrm{pH}$ 를 측정한 결 과, IR 품종에서 가장 높았고, 당도와 고형분 함량은 CS 품종에 서 가장 높았다. Valine, leucine, isoleucine, serine, alanine 및 glutamic acid 모두 CS 품종에 가장 많이 함유되어 있었다. 커피 의 품질에 부정적인 영향을 미치는 caffeine과 theobromine 함
량은 IR품종에서 가장 많은 반면, 커피의 품질에 긍정적인 영향을 미치는 trigonelline과 chlorogenic acid는 CSD 품종에 가장 많이 함유되어 있었다. DPPH radical 소거능은 또한 CS품종에 가장 높게 나타났다.

결론적으로 5 종류의 스페셜티 커피 중 고형분 함량이 많 고 $\mathrm{DPPH}$ radical 소거능이 우수한 CS 품종과 trigonelline, chlorogenic acid의 함량이 높은 CSD 품종을 블렌딩하면, caffeine 함량이 낮아 건강상 유리하면서, 고형분, trigonelline, chlorogenic acid 함량이 높은 품질의 스페셜티 커피로 제조될 수 있을 것이라 판단된다.

\section{Author's contribution}

AJK, a messenger, personally conducted and accepted the research and design supervision of this paper. The first author, SYL, collected coffee samples focusing on the study design of the messenger, and carried out all the experiments in the paper herself. The second author, MRH, was responsible for reviewing the experimental design in detail and correcting the errors directly. All authors read and approved the final manuscript.

\section{Author details}

So-Young Lee (Graduate student), Department of Alternative Medicine, Kyonggi University, 63, Kyonggidaero-9 gil, Seodaemun-gu, Seoul 03752 Korea; Myung-Ryun Han (Associate Professor), Department of Baking Science \& Technology, Hyejeon University, 19, Daehak-1gil, Hongsung-eup, Hongsung-gun. Chungnam-do 32244, Korea; Ae-Jung Kim (Professor), Department of Nutrition Therapy, The Graduate School of Alternative Medicine, Kyonggi University, 63, Kyonggidae-ro-9 gil, Seodaemungu, Seoul 03752 Korea.

\section{References}

Blois MS. Antioxidant determinations by the use of a stable free radical. Nature, 181: 1199-1200, 1958.

Choi MJ, Lee JY. Effects of caffeine on bone mineral density and bone mineral content in ovariectomized rats. Korean Journal of Nutrition, 41: 216-223, 2008.

Choi SH. Changes in the composition of catechins, theaflavins and alkaloids in leaves from Korean Yabukida tea plant during processing to fermented black tea. 
Journal of Korean Society of Food Culture, 24: 308-314, 2009.

Colonna-Dashwood M. The coffee dictionary: an A-to-Z of coffee, from growing $\&$ roasting to brewing $\&$ tasting. Mitchell Beazley, London, pp1-13, 2017.

Eun JB, Jo MY, Im JS. Physicochemical characteristics of coffee extracts using different extraction methods. Korean Journal of Food Science and Technology, 46: 723-728, 2014.

Franca AS, Mendonça JC, Oliveira SD. Composition of green and roasted coffees of different cup qualities. LWT-Food Science and Technology, 38: 709-715, 2007.

Flament I. Coffee flavor chemistry. John Wiley \& Sons, New York, pp16-166, 2002.

Jang EH, Nam D, Na HG, Chae HS, Lee DH, Kim MJ, Kim $\mathrm{HH}$, Lee JH, Jang KH. Comparison of physicochemical properties and antioxidant activities of commercial regular coffee and instant coffee with coffee creamer. Journal of the East Asia Society of Dietary Life, 27: 540547, 2017.

Jeong JS, Lee ES. The efficiency measurements of abdominal obesity management through the massage with caffeine and the subjective evaluation after massage. Asian Journal of Beauty and Cosmetology, 11: 1117-1127, 2013.

$\mathrm{Ji} \mathrm{JH}$, Lee SH. Analysis of the demand for imported coffee bean in Korea. Journal of Korean Agriculture Management and Policy, 46: 1-16, 2019.

Karakaya S, EI SN, Taş AA. Antioxidant activity of some foods containing phenolic compounds. International Journal of Food Science and Nutrition, 52: 501-508, 2001.

Kim DH, Yeon SJ, Jang KI. Quality characteristics and antioxidant activity of espresso coffee prepared with green bean fermented by lactic acid bacteria. Journal of the Korean Society of Food Science and Nutrition, 45: 1799-1807, 2016.

Kim EH, Lee WK. The political-economic meanings of coffee through coffee history. Journal of Tourism Industry Studies, 9: 35-55, 2015.

Kim E. Connecting specialty coffee with fair travel: focusing on changing coffee industry and government policy in Indonesia. Journal of the Association of Korean PhotoGeographers, 26: 135-151, 2016.

Kim HK, Hwang SY, Yoon SB, Chun DS, Kong SK, Kang KO. A study of the characteristics of different coffee beans by roasting and extracting condition. The Korean Journal of Food and Nutrition, 20: 14-19, 2007.

Kim JY, Han YS. Influence of roasting time on antibacterial and antioxidative effects of coffee extract. Korean Journal of Food and Cookery Science, 25: 496-505, 2009.

Kim KJ, Park SK. Changes in major chemical constituents of green coffee beans during the roasting. Korean Journal of Food Science and Technology, 38: 153-158, 2006.

Kim SH, Kim JS. Chemical composition and sensory attributes of brewed coffee as affected by roasting conditions. Culinary Science and Hospitality Research, 23: 1-11, 2017.

Kim SJ, Chung SH. The effect of caffeine on human body. FoodService Industry Journal, 13: 333-344, 2017.

Ko JK, Jung, JH, Yoon HH. Sensory quality characteristics of Colombia coffee under various processing and roasting conditions of green beans. Journal of the East Asian Society of Dietary Life, 27: 365-377, 2017.

Lee $\mathrm{CH}$, Yi HR. A study on the influence of the selection attributes of roastery coffee shop on customer satisfaction and revisitation. Journal of Foodservice Management, 19: 177-199, 2016.

Lee EH, Park DH, Kwon HJ. Nutritional and functional characterization of coffee cherry husk extract (CHE) for estimation of utility as raw material for cosmetics. Asian Journal of Beauty and Cosmetology, 11: 497-488, 2013.

Lee KS, Kim JM, Yoon KY. Physicochemical properties, bioactive composition, and antioxidant activity of different coffee beans dependent on the cultivation region. Korean Journal of Food Science and Technology, 49: 474-479, 2017.

Lim YK. The effects of caffeinated beverage intake on serum iron (Fe) and total iron binding capacity (TIBC). Korean Association of Addiction Crime Review, 7: 93-112, 2017.

Mongraw-Chaffin ML, Cohn BA, Anglemyer AT, Cohen RD, Christianson RE. Maternal smoking, alcohol, and coffee use during pregnancy and son's risk of testicular cancer. Alcohol, 43: 241-245, 2009.

Nakanishi N, Nakamura K, Nahajima K, Suzuki K, Tatara $K$. Coffee consumption and decreased serum gammaglutamyltransferase; a study of middle-aged Japanese 
men. European Journal of Epidemiology, 16: 419-423, 2000.

Park YJ, Lee SJ, Shin NM, Shin H, Kim YK, Cho Y, Jeon S, Cho I. Bone mineral density, biochemical bone turnover markers and factors associated with bone health in young Korean women. Journal of Korean Academy of Nursing, 44: 504-514, 2014.

Sacchetti G, Di Mattia C, Pittia P, Mastrocola D. Effect of roasting degree, equivalent thermal effect and coffee type on the radical scavenging activity of coffee brews and their phenolic fraction. Journal of Food Engineering, 90: 74-80, 2009.

Seo HS, Kang HJ, Jung EH, Hwang IK. Application of GC-SAW electronic nose classification of origins and blended commercial brands in roasted ground coffee beans. Korean Journal of Food and Cookery Science, 22: 299306, 2006.

Seo HS, Kim SH, Hwang IK. Comparison on physicochemical properties and antioxidant activities of commonly consumed coffees at coffee shops in Seoul downtown. Korean Journal of Food and Cookery Science, 19: 624-
630, 2003.

Shin MG, Kim KJ, Kim KI. A study of consumers' selection properties of roastery coffee house and roasting conditions of coffee. Journal of Foodservice Management, 21: 215-236, 2018.

Shin WR, Choi YM, Yoon HH. The sensory characteristics of espresso according to grinding grades of coffee beans. Korean Journal of Food and Cookery Science, 27: 8599, 2011

Yeon JY, Bae YJ. Coffee consumption and the risk of abdominal obesity as defined by waist circumference in Korean women: based on 2012 2016 Korea national health and nutrition examination survey. The Korean Journal of Food and Nutrition, 32: 69-78, 2019.

You JW, Lee SE. Effects of coffee and caffeine ingestion on energy metabolism in upper extremity exercise. The Korea Society of Sports Science, 27: 963-972, 2018.

Yun SS, Kim H, Jang SJ, Lim HS, Kim SH, Kim M. Simultaneous determination of caffeine, theobromine and theophylline in tea leaves by HPLC. Korean Journal of Food Science and Technology, 47: 556-560, 2015. 


\section{국문초록}

\section{원산지에 따른 스페셜티 커피의 품질특성}

이소영 ${ }^{1}$, 한명륜 ${ }^{2}$, 김애정 ${ }^{*}$

${ }^{1}$ 경기대학교 대체의학과, 서울, 한국

${ }^{2}$ 혜전대학교 제과제빵과, 충청남도 홍성군, 한국

${ }^{3}$ 경기대학교 대체의학대학원 식품치료전공, 서울, 한국

목적: 본 연구에서는 소비자에게 가장 우수한 스페셜티 커피 품종을 제시하고자 최근 수입량이 지속적으로 늘고 있는 Colombia Supremo (CS), Costa-rica Tarrazu (CT), Colombia Supremo Decaffeine (CSD), Indonesia Mandelling (IM), India Robusta (IR) 5 종류를 샘플링하여 그 품질특성을 평가하였다. 방법: 5 종류의 스페셜티 커피 생두를 각각 로스팅 한 후 추출하여 $\mathrm{pH}$, 당도, 고형분 함량, caffeine, theobromine, trigonelline, chlorogenic acid 함량 및 $\mathrm{DPPH}$ radical 소거능을 측정하였다. 결과: $\mathrm{pH}$ 를 측정한 결과, $\mathrm{IR}$ 이 $5.71 \pm 0.01$ 로 가장 높았고, 당도와 고형분 함량은 CS가 $1.20 \pm 0.10$ 및 $0.83 \pm 0.05{ }^{\circ} \mathrm{Brix}$ 로 가장 많았다. 총 분지사슬 아미노 산( Branched chain amino acid, BCAA) 함량 $(63.58 \pm 0.12 \mathrm{mg} / \mathrm{g})$ 과 맛 관련 아미노산인 serine, alanine, glutamic acid 함량(67.84 $\pm 0.10 \mathrm{mg} / \mathrm{g}$ )도 CS가 가장 많았다. caffeine과 theobromine의 함량 $(29.32 \pm 0.07 \mathrm{mg} / \mathrm{g}, 0.74 \pm 0.01 \mathrm{mg} / \mathrm{g})$ 은 $\mathrm{RR}$ 에 가장 많았으며, trigonelline과 chlorogenic acid 함량 $(0.97 \pm 0.02 \mathrm{mg} / \mathrm{g}, 0.94 \pm 0.01 \mathrm{mg} / \mathrm{g})$ 은 CSD가 가장 많았다. DPPH radical 소거능은 CS가 $90.54 \pm 0.18 \%$ 로 가장 높게 나타났다. 결론: 5 종류의 스페셜티 커피 중 CS 품종은 맛 관련 아미노산함량과 DPPH radical 소거능이 우수하였으며, CSD 품종에는 trigonelline와 chlorogenic acid의 함량은 높고 카페인 함량은 낮았다. 따라서 두 품종의 스페셜티 커 피를 블랜딩하면 카페인 함량은 낮고 맛과 항산화 활성이 우수한 새로운 스타일의 스페셜티 커피로 제조될 것으로 판단된다.

핵심어: 스페셜티 커피, 카페인, 테오브로민, 트리고넬린, 클로로제닉산

\section{참고문헌}

고재광, 정진혁, 윤혜현. 콜롬비아 커피생두의 가공법과 로스팅에 따른 품질 특성. 동아시아식생활학회지, 27: 365-377, 2017.

김관중, 박승국. 커피 원두의 배전공정 중 변화되는 주요 화학성분에 대한 연구. 한국식품과학회지, 38: 153-158, 2006. 김동호, 연수지, 장금일. 유산균 발효 생두를 이용한 에스프레소 커피의 품질 특성 및 항산화 활성. 한국식품영양과학회지, 45: 1779-1807, 2016.

김성혜, 김주신. 로스팅 조건 변화에 따른 커피 추출액의 화학성분 및 관능 특성. 한국조리학회지, 23: 1-11, 2017.

김수진, 정승호. 카페인이 인체에 미치는 영향. 한국외식산업학회지, 13: 333-344, 2017.

김은희, 이웅규. 커피역사를 통해 본 커피의 정치경제적 개념. 관광산업연구, 9: 35-55, 2015.

김이재. 스페셜티 커피와 공정여행의 연계: 인도네시아 커피산업과 정책 변화를 중심으로. 한국사진지리학회지, 26: 135-151, 2016.

김지영, 한영숙. 배전시간에 따른 커피 추출물의 항균 및 항산화 효과. 한국식품조리과학회지, 25: 496-505, 2009.

김하경, 황성연, 윤수봉, 천덕상, 공석길, 강근옥. 종류의 커피의 볶음 및 추출조건에 따른 품질 특성에 관한 연구. 한국식 품영양학회지, 20: 14-19, 2007.

박영주, 이숙자, 신나미, 신현정, 김유경, 조윤정, 전송이, 조인해, 성인초기 여성의 골밀도, 생화학적 골표지자 및 골건강 관련 요인. 한국간호과학회지, $44: 504-514,2014$.

서한석, 강희진, 정은희, 황인경. GC-SAW (Surface Acoustic Wave) 전자코를 활용한 볶은 커피의 원산지 및 배합 커피 의 상품별 분류. 한국식품조리과학회지, 22: 299-306, 2006. 
서한석, 김수희, 황인경. 서울 시내 커피전문점에서 판매되는 커피의 이화학적 특성 및 항산화성 비교. 한국식품조리과학 회지, 19: 624-630, 2003.

신미경, 김광진, 김경임. 소비자의 로스터리 커피전문점 선택과 로스팅 조건에 관한 연구. 외식경영연구, 21: 215-236, 2018.

신우리, 최유미, 윤혜현. 커피원두의 분쇄입자크기에 따른 에스프레소의 관능적 특성. 한국식품조리과학회지, 27: 85-99, 2011.

은종방, 조미연, 임지순. 커피의 추출방법에 따른 이화학적 특성. 한국식품과학회지, 46: 723-728, 2014.

연지영, 배윤정. 성인 여성에서 커피 섭취와 허리둘레를 기준으로 한 비만과의 관련성: 2012 2016 국민건강영양조사 자 료를 이용하여. 한국식품영양학회지, 32: 69-78, 2019.

유정완, 이소은. 커피 및 카페인 섭취가 상지운동 시의 에너지 기질에 미치는 영향. 한국체육과학회지, 27: 963-972, 2018.

윤상순, 김현, 장수진, 임호수, 김신희, 김미혜. $\mathrm{HPLC}$ 를 이용한 다류 중 카페인, 테오브로민과 테오필린 동시분석 및 함량 조사. 한국식품과학회지, 47: 556-560, 2015.

이경수, 김자민, 윤경영. 원산지에 따른 커피의 이화학적 특성, 생리활성 성분 및 산화방지 활성. 한국식품과학회지, 49 : 474-479, 2017.

이윤배, 류근걸, 이종권, 성시창, 신은정. 천연물로부터 카페인 추출에 관한 연구. 한국산학기술학회 학술대회 논문집, 6 : 294-296, 2004.

이은희, 박두현, 권혜진. 화장품 원료로서 커피체리 껍질 추출물의 영양 및 기능적 특성 연구. 아시안뷰티화장품학술지, 11: 479-488, 2013

이초희, 이혜련. 로스터리 커피전문점의 선택속성이 고객만족 및 재방문에 미치는 영향연구. 외식경영연구, 19: 177199, 2016.

임용광. 카페인이 함유된 음료 섭취가 혈청 철, 총 철 결합능에 미치는 영향. 한국중독범죄학회보, 7: 93-112, 2017.

장은호, 남동훈, 나하균, 채희성, 이동하, 김민주, 김희훈, 이제혁, 장기효. 국내 시판 레귤러 커피와 커피 크리머 첨가커피 의 이화학적 특성 및 항산화력 비교. 동아시아식생활학회지, 27: 540-547, 2017.

정재선, 이은실. 카페인성분을 이용한 마사지와 마사지 후의 주관적 평가를 통한 복부 비만관리의 효율적 방안에 대한 연 구. 아시안뷰티화장품학술지, 11: 1117-1127, 2013.

지정훈, 이상현. 수입 커피생두에 대한 국내 수요 분석. 농업정책연구, 46: 1-16, 2019.

최미자, 이주영. 난소절제 쥐에서 카페인 첨가식이가 골밀도 및 골함량에 미치는 영향. 한국영양학회지, 41: 216-223, 2008. 


\section{中文摘要}

\section{按产地划分的进口特种咖啡的质量特征}

李素英 ${ }^{1}$, 韓明倫 $^{2}$, 金愛貞 $^{3 *}$

京畿大学代替医疗学科, 首尔, 韩国

慧田大学烘焙科学与技术学科, 忠清南道洪城郡, 韩国

3京畿大学代替医疗大学院食品治疗学科，首尔，韩国

目的: 这项研究旨在通过对五种咖啡 Colombia Supremo (CS), Costa-rica Tarrazu (CT), Colombia Supremo Decaffeine (CSD), Indonesia Mandelling (IM), India Robusta (IR)的五种咖啡进行抽样并评估其质量特征, 从 而确定最适合客户的特色咖啡。方法: 焙烧后提取五种特色咖啡豆, 测定其 $\mathrm{pH}$, 糖度, 固形物含量, 咖啡因, 可可碱, 揫芦碱和绿原酸含量, 以及DPPH清除能力。结果: IR的 $\mathrm{pH}$ 值最高为 $5.71 \pm 0.01, \mathrm{CS}$ 的糖度和固体含 量最高, 分别为 $1.20 \pm 0.10,0.83 \pm 0.05^{\circ} \mathrm{Brix}$ 。同时CS的总支链氨基酸 $(63.58 \pm 0.12 \mathrm{mg} / \mathrm{g}$ ）和与口味相关 的氨基酸的总和, 如丝氨酸, 丙氨酸, 谷氨酸 $(67.84 \pm 0.10 \mathrm{mg} / \mathrm{g})$ 最高。IR的咖啡因含量和可可碱含量最 高 (分别为 $29.32 \pm 0.07 \mathrm{mg} / \mathrm{g}$ 和 $0.74 \pm 0.01 \mathrm{mg} / \mathrm{g}$ ) 。同时, CSD表现出的松果酸和绿原酸含量最高（分别为 $0.97 \pm 0.02 \mathrm{mg} / \mathrm{g}$ 和 $0.94 \pm 0.01 \mathrm{mg} / \mathrm{g}$ ）。CS的DPPH自由基清除活性为 $90.54 \pm 0.18 \%$, 在被测咖啡中最高。结 论: 在这五种特色咖啡中, CS 具有较高的固含量和优异的DPPH自由基清除活性, 而CSD的松果茶碱和绿原酸含 量较高, 而咖啡因含量较低。如果将它们混合, 则这种新的特种咖啡将具有高水平的抗氧化活性, 并具有良好 的口感和少量的咖啡因。

关键词: 特色咖啡, 咖啡因, 可可碱, 曲古林, 绿原酸 